MUZEUL NAȚIONAL DE ISTORIE A ROMÂNIEI

\title{
CERCETĂRI ARHEOLOGICE
} XII

Editor: Dr. Crişan Muşețeanu 
ISSN 0255-6812 


\section{CERCETĂRI ARHEOLOGICE}

XII

BUCUREŞTI

2003 
Editor: Dr. Crişan Muşețeanu

Redactor şef: Dragomir Popovici

Tehnoredactare: Daniela Iacovache, Cristina Joiţa Desene: Georgiana Ducman, Corina Dănilă

Foto: Marius Amarie

Coperta: Andrei Mărgărit

\section{Colectivul de redacție:}

Dr. Gheorghe Trohani

Dr. Liviu Petculescu

Dr. Anca Păunescu 


\section{CUPRINS}

\section{EMIL CONDURACHI}

REPERE BIOGRAFICE

Răzvan Theodorescu - Profesorul meu $\quad 15$

$\begin{array}{ll}\text { Zoe Petre - Pater } & 16\end{array}$

Alexandru Vulpe - Emil Condurachi - director 18

Mircea Petrescu-Dîmbovița - Academicianul Emil Condurachi la 90 ani de la naşstere 20

Ion Barnea - Emil Condurachi şi arheologia creştină

Alexandru Suceveanu - 90 de ani de la naşterea lui Emil Condurachi 29

Mihai Bărbulescu - Emil Condurachi - 90 de ani de la naştere 32

Constantin Preda - Profesorul Emil Condurachi-numismatul 34

Gavrilă Simion - Un cuvânt pentru profesorul meu

Mihai Irimia - Emil Condurachi Şi Dobrogea $\quad 40$

\section{RAPOARTE DE SĂPĂTURĂ}

Radu Coman, Elena Rența, Gh. Matei, Silviu Oța - Raport de cercetare arheologică pe anii 2001-2003 la Oraşul de Floci (com. Giurgeni, jud. Ialomița)

\section{ARTICOLE}

Radian Romus Andreescu, Traian Popa - Sultana-Malu Roşu. Catalog selectiv 59

Radian Romus Andreescu, Pavel Mirea, Ștefan Apope - Cultura Gumelnița în vestul Munteniei. Aşezarea de la Vităneşti, jud. Teleorman

Doina Leahu - Considerații cu privire la falerele de aur din epoca bronzului descoperite pe teritoriul României. 
Sorin Oanță-Marghitu - "Fenomenul Cernavoda III-boleráz": după 30 de ani

Rodica Boroffka, George Trohani - Necropola getică de la Canlia, com. Lipnița, jud.

Constanța

Doina Şeclăman, Marin Şeclăman, George Trohani - Contribuții la studiul ceramicii getice din Câmpia Română

Mircea Negru, Alexandru Bădescu, Romeo Avram - Amfore de tip käpitan II în Dacia romană

Silviu Oța, Katiuşa Pârvan - Monede medievale descoperite la Piua Petrii în campaniile arheologice din anii 1996, 1998-1999 (I)

Anca Păunescu, Eugen S. Teodor - L'établissement rural médiéval des XVI-XVII siecles de Brăneşti-Vadu Anei

\section{STUDII}

Mircea Anghelinu - Note privind impactul marxismului în teoria şi practica arheologiei preistorice din România

Dragomir Popovici - Area organization, arrangement and use in the Cucuteni, phase A Culture (I)

Eugen Silviu Teodor - O frontieră incertă a lumii romane - Câmpia Dunării de Jos în epoca lui Justinian

\section{CERCETĂRI PLURIDISCIPLINARE}

Adrian Bălăşescu, Valentin Radu - Studiul materialului faunistic descoperit in tell-ul de la Vităneşti (jud. Teleorman): nivelul Gumelniţa $B_{1}$

Constantin Haită, Valentin Radu - Les zones de rejets menageres de la culture Gumelnita: temoins dans l'evolution chrono - stratigraphique des tells. Etude micro-morphologique et archaeo-ichthyologique sur le tell d'Hârsova (dep. Constanța).

\section{NOTE}

Elvira Ciocea Safta - Un ac de bronz cu cap globular din Transilvania 
Lia Bătrîna, Adrian Bătrîna - Precizări cu privire la unele reprezentări de pe inele medievale din secolele XIV-XV

Adina Boroneanț, Mihai Vasile - Protecția monumentelor istorice în România. Partea I-a legislația şi aplicarea ei anterior anului 1989

\section{RECENZII}

Crişan Mușețeanu - Kevin Greene, The Pre Flavian Fine Wares, Report un the Excavations at Usk 1965-1976 University of Wales Press, Cardiff, 1979, 165 p., 55 figures.

Crişan Mușețeanu - Tatyana Cvjecticanin, Glazed pottery from Upper Moesia, Beograd, 2001, 149 pages, 8 illustrations, 2 maps.

Crişan Muşețeanu - Ioan C. Opriş, Ceramica romană târzie şi paleobizantină de la Capidava in contextul descoperirilor de la Dunărea de Jos (sec IV - VI p. Chr) 241 pagini, 64 planşe, editura Enciclopedică, Bucureşti 2003.

Silviu Teodor - Florin Curta - The Making of Slavs: History and archaeology on the Lower Danube Region, cca. 500-700 Oxford University Press, 2001 (350 p. + două anexe, index, bibliografie)

Rodica Oanță-Marghitu - Éva Garam, Funde byzantinischer Herkunft in der Awarenzeit vom Ende des 6. Bis zum Ende des 7. Jahrhunderts, în Monumenta Avarorum Archaeologica, Vol 5, Budapesta, 2001; 24 de figuri în text, 139 de planşe alb-negru, 60 de planşe color şi o anexă

\section{Necrolog}

\section{Radu Florescu}




\title{
CONSIDERAȚII CU PRIVIRE LA FALERELE DE AUR DIN EPOCA BRONZULUI DESCOPERITE PE TERITORIUL ROMÂNIEI.
}

\author{
Doina Leahu
}

\section{Résumé}

Abordant le problème des phalères en or, les chercheurs se sont parfois rencontré, d'une manière objective, avec les difficultés concernant l'encadrement de certaines pièces dans cette catégorie. Autrefois, l'impossibilité d'opérer une stricte délimitation, d'après des critères morphologiques et fonctionnels de cet artéfact en rapport avec d'autres, de la catégorie des parures, a conduit à des hésitations et même à des encadrements erronés pour une partie des objets. On peut affirmer qu'une précise définition du type d'objet - la phalère, dans notre cas - représente un instrument de travail nécessaire et important. La définition donné par l'historien d'art Radu Floresco, dans le «Dicționar enciclopedic de artă veche românească» (Bucarest, 1980), nous apparaît comme étant la plus complète et correcte, ayant comme fondement des essentiels critères de présentation de l'objet: la forme qui le caractérise, le matériel, la fonctionnalité, la circulation et l'évolution pendant le temps.

Le patrimoine des phalères en or découvertes jusqu'à présent en Roumanie compte entre 79-84 pièces de 10 endroits. Le nombre exact est difficile d'établir, à peu près toutes proviennent de découvertes fortuites, beaucoup d'entre elles n'étant pas correctement présentées. Seulement trois découvertes de phalères (Beba Veche, Pecica et Vărşand) peuvent être rapportées avec certitude à un certain contexte archéologique.

D'après leur forme les phalères peuvent être groupées en deux catégories: ovales (Beba Veche) et circulaires (les autres). D'après leur profil, on a des phalères plates (Beba Veche) et convexo-concaves (de nouveau toutes les autres). Les dernières se caractérisent par la présence d'un ombon central.

Tous les exemplaires ont un unique système d'accrochement: à l'aide d'orifices circulaires marginaux, diamétralement disposés - une seule exception, la phalère de Pecica-Rovine qui a les orifices dans le champ.

Toutes les pièces sont ornementées, souvent le décor étant répandu sur toute la surface. Les plus richement décorées sont les phalères de Săcuieni, Ostrovu Mare, Grăniceri et les grandes phalères de Tufalău. Le rôle décoratif des phalères a été unanimement apprécié.

Les phalères en or découvertes sur le territoire de la Roumanie ont été utilisées pendant l'époque du bronze surtout comme parures pour les vêtements et le corps, fait prouvé par la découverte des pièces dans des tombes de Beba Veche et confirmé par le système d'accrochement - qui délimitent les exemplaires en or de ceux en bronze qui contiennent une anse d'accrochement. Le même détail morphologique sépare les phalères en or d'autres parures aux accessoires de vêtements (tutuli, boutons), précision qui s'impose parce que dans la littérature scientifique on constate parfois des confusions et des erreurs. La possibilité d'utiliser les phalères comme pièces de harnachement - disques pour selle - a été admise par Amália Mozsolics.

La valeur intrinsèque et leur esthétique a part ont offert aux phalères en or non seulement une fonction décorative, mais aussi les attributions propres des artéfacts destinés à un acte cérémonial fréquent pendant l'existence des collectivités humaines préhistorique; quelques pièces, plus grandes et somptueusement décorées, représentaient des symboles du pouvoir.

D'un point de vue justifié, beaucoup de scientifiques on fait une liaison entre les phalères en or de Roumanie avec des pièces similaires de la Grèce mycénienne, fait qui ne peut être contesté. Mais, de même, on doit remarquer aussi une ascendance typologique locale, prouvée depuis le néolithique par les disques coniques en cuivre et or, parfois décoré «au repoussé» avec des enfilades de points et ayant des orifices d'accrochement. Des pareils objets de parure on a découvert en Roumanie (à Hăbăşseşti et Brad), en Bulgarie (à Varna), en Hongrie (à Gyoma). Une éventuelle évolution vers les phalères de la période moyenne de l'époque du bronze carpatho-danubien pourrait être aperçu par la pièce en forme de calotte demisphèrique et par une petite phalère, en or, découvertes à Pecica (dép. de Arad).

La réalisation des phalères en or de l'époque du bronze, du territoire de la Roumanie, peut être attribuée, avec certitude, à la population locale - les thraces du nord. Comme arguments, dans les 
ouvrages scientifiques, on peut mentionner: la provenance de Transylvanie de l'or utilisé, la présence de certains segments d'or brut dans le contenu des trésors de Țufalău et Şmig, l'encadrement du décor des phalères dans le répertoire des motifs et la syntaxe décorative propres aux civilisations Mureş (les pièces de Beba Veche et Pecica-Rovine), Wietenberg (les exemplaire des trésors de Şmig et Țufalău et ceux de Săcuieni), Otomani (la phalère de Vărşand), Gârla Mare (le trésor d'Ostrovu Mare) etc.

La chronologie - relative et absolue - des phalères en or de Roumanie a beaucoup changé pendant le temps, d'après les progrès faites par l'archéologie dans le domaine de la datation de l'époque du bronze. Pour le moment on peut admettre la datation des pièces de Beba Veche pendant le Bronze ancien et toutes les autres pendant le Bronze moyen. Exception font les trois phalères de Grăniceri (Otlaca) qui peuvent dater du Bronze récent.

En ce qui concerne la datation absolue, la récente opinion du prof. Alexandre Vulpe, qui situe le Bronze moyen de l'espace carpatho-danubien entre les années 2300-1600/1500 av. J.C., nous invite à «monter» les datations admises jusqu'à présent (XVIe-XVe siècle av. J.C.).

Relativ puțin numeroase, dar dovedindu-se - prin ornamentarea lor, strâns legată de cea a ceramicii populațiilor locale - caracteristice şi reprezentative pentru civilizația epocii bronzului de pe teritoriul României, falerele de aur nu au constituit totuşi obiect de studiu pe măsura interesului şi valorii lor.

Literatura de specialitate românească şi străină cu referire la acest subiect este restrânsă, iar în unele cazuri (lucrările elaborate mai demult) depăşită. Astfel, unele opinii formulate de Vasile Pârvan în deceniul al treilea al secolului trecut despre tehnica de ornamentare a falerelor de aur sau asupra încadrării lor cronologice $^{1}$ - au fost infirmate de descoperiri şi studii ulterioare. Ideea unor relații de ordin tipologic şi cultural între falerele de aur din România şi piese de bronz decorate din nordul Europei, vehiculată de I. Nestor şi F. Tompa ${ }^{2}$ în anii treizeci, preluată apoi şi de Dorin Popescu care opina că "ornamentaţia falerelor de la Săcuieni şi Vărşand, de pildă, este înrudită de aproape cu cea de pe bronzurile şi mai ales de pe văscioarele de atârnat din nord, aparținând perioadelor Montelius V şi VI" ${ }^{3}$

\footnotetext{
1 Vasile Pârvan, Getica. O protoistorie a Daciei, București, 1926, p. 342,450.

${ }^{2}$ Ion Nestor, Der Stand der Vorgeschichtsforschung in Rumänien, în 22. Bericht der Römisch-Germanisch Kommision, Frankfurt, a. Main, 1933, p.121; F. Tompa, în Archaeologya Értesitö, 1937, p. 49-56.

3 Dorin Popescu, în Materiale şi cercetări arheologice, II, 1956, p. 237.
}

- nu mai este acceptată şi reținută. Totuşi analiza efectuată în urmă cu jumătate de secol de Dorin Popescu în studiul său "Prelucrarea aurului în Transilvania înainte de cucerirea romană" ${ }^{4}$ prezintă în continuare interes, chiar dacă apare tributară stadiului de atunci al informației. Tot astfel poate fi apreciată şi prezentarea făcută de Vladimir Dumitrescu în cartea sa "Arta preistorică în România", editată în 1974, care se remarcă prin rigurozitatea şi acuratețea descrierii materialului, fără însă a face referiri la problematica încadrării cronologice şi culturale, a evoluției sau semnificației acestui tip de podoabă ${ }^{5}$. O informație riguros selectată şi verificată, împreună cu soluții propuse pentru datarea şi atribuirea culturală a falerelor de aur preistorice din spaţiul carpato-dunărean - soluții care, e adevărat, nu mai sunt şi nu mai pot fi în întregime însuşite - se regăsesc în lucrarea, rămasă până în prezent de referință, a cercetătoarei maghiare Amália Mozsolics, "Goldfunde des Depotfundhorizontes von Hajdusámson" ${ }^{6}$, apărută în 1968. În fine, trebuie reținute consemnarea detaliată a falerelor de către Radu Florescu în "Dicționar enciclopedic de artă veche a României", apărut în 1980 şi cu deosebire observatiiile de maximă pertinență asupra ornamenticii şi funcționalității pieselor, chiar dacă pe alocuri se resimte

\footnotetext{
${ }^{4}$ Dorin Popescu, op. cit., p. 196-250.

5 Vladimir Dumitrescu, Arta preistorică în România, Bucureşti, 1974, p. 401-407.

${ }^{6}$ Amália Mozsolics, în 46-47. Bericht der Römisch.Germanisch Kommision, 1965-1966, (1968), p. 28-34.
} 
amprenta - cu limitele specifice - a genului lucrării în care obiectele au fost înseriate ${ }^{7}$.

Abordând problematica falerelor de aur din epoca bronzului de pe teritoriul României trebuie să observăm că uneori, în mod obiectiv, cercetătorii au întâmpinat dificultăți la încadrarea unor piese în acest tip categorial, denumit frecvent în literatura de specialitate discuri de aur. Pentru a exemplifica, notăm că obiectele descoperite la Beba Veche au fost definite de Dorin Popescu ,plăci ornamentale”, în timp ce Vladimir Dumitrescu şi Radu Florescu leau inclus fără rezerve în grupul falerelor ${ }^{8}$. Alteori, imposibilitatea de a opera o delimitare strictă, pe criterii morfologice şi functionale, a acestui artefact în raport cu altele - nasturi sau tutuli, de exemplu - din aceeaşi categorie a podoabelor, a condus la ezitări şi chiar încadrări eronate ale unor obiecte, aspect asupra căruia vom reveni. Credem de aceea că o definire precisă a tipului de obiect însuşi - faleră, în cazul de față - constituie un instrument de lucru nu numai necesar dar şi important pentru studierea sa.

Într-o definiție de dicționar datorată istoricului de artă Radu Florescu, falera este apreciată ca ,element de podoabă discoidal, de obicei din metal prețios, care se folosea ca aplică de costum sau de harnaşament, ca pandantiv de harnaşament, ca ornament de fibulă, sau în grupări de mai multe piese, în coliere" . Este în opinia noastră cea mai cuprinzătoare şi corectă prezentare, ea întemeindu-se pe criterii esențiale de definire a obiectului în discuție: forma care îl particularizează şi materialul utilizat; funcționalitatea; circulația şi evoluția sa pe parcursul mai multor epoci.

\footnotetext{
${ }^{7}$ Radu Florescu, Hadrian Daicoviciu, Lucian Roșu, Dicționar enciclopedic de artă veche a României, Bucureşti, 1980, p. 22, 46, 57, 174, 249, 253-254, 264, 301, 327-328, 348, 359.

8 Dorin Popescu, op. cit., p. 206-207; Vladimir Dumitrescu, op. cit., p. 401; Radu Florescu, în op. cit., p. 57.

${ }^{9}$ Radu Florescu, în op. cit., p. 151.
}

Patrimoniul falerelor de aur descoperite până în prezent pe teritoriul României însumează între 79 şi 84 exemplare întregi şi fragmente din alte 4 falere, recoltate din 10 localități: 1) Adoni, comuna Tarcea, județul Bihor - 1 faleră; 2) Beba Veche sat, comună, județul Timiş - 2 exemplare; 3) Grăniceri sat, comună, județul Arad - 3 falere; 4) Ostrovu Mare sat, comuna Gogoşu, județul Mehedinți - 33 falere; 5) Pecica sat, comună, județul Arad - 1 exemplar; 6) Săcuieni sat, comună, județul Bihor - 3 falere întregi şi un fragment de faleră; 7) Şmig sat, comuna Ațel, județul Sibiu - 26 falere; 8) Transilvania, localitate necunoscută -1 piesă; 9) Țufalău sat, comuna Boroşneu Mare, județul Covasna -8 sau 13 falere întregi şi fragmente din alte 3 exemplare; 10) Vărşand sat, comuna Pilu, județul Arad - 1 faleră. (Detalii în anexa-catalog).

Numărul sigur al obiectelor este greu să fie stabilit, deoarece toate exemplarele cunoscute provin din descoperiri întâmplătoare, care adeseori nici nu au fost prezentate riguros, corect. Aspectul a fost remarcat şi de Dorin Popescu, care a apreciat că "s-ar putea să mai existe şi altele (falere n.m.)" şi că "descrierea descoperirilor...de cele mai multe ori nu este suficient de clară" $^{10}$. În asemenea împrejurări s-au putut înregistra şi pierderi de obiecte. Este cazul descoperirii de la Săcuieni, dintre cele 8 falere găsite întâmplător păstrându-se doar 3, fără a se putea şti împrejurările dispariției celorlalte. O situație deosebită o reprezintă cunoscutul tezaur de la Țufalău. Contextul istoric în care s-a făcut în 1840 descoperirea - Transilvania era inclusă atunci în Imperiul Austriei - a dus la dispersarea pieselor în muzee din Budapesta şi Viena, cauzând confuzii evidente în stabilirea numărului exact al pieselor ce îl alcătuiesc. Aşa s-ar putea explica de ce Dorin Popescu şi Radu Florescu atribuie tezaurului 10 falere de aur 8 întregi şi două fragmente; de ce Amália Mozsolics consemnând la Naturhistorisches Museum din Viena 6 falere întregi şi

\footnotetext{
${ }^{10}$ Dorin Popescu, op. cit., p. 210.
} 
fragmente din altele 3, iar la Muzeul Național din Budapesta două falere mari întregi, nu exclude posibilitatea apartenenței la tezaur a încă 5 exemplare (păstrate la Muzeul din capitala Ungariei) al căror loc de descoperire este incert dar care sunt frapant asemănătoare falerelor mici aflate la Viena ${ }^{11}$. Remarcăm totuşi şi similitudinea perfectă a unuia dintre exemplarele în discuție cu 3 falere mici din tezaurul de la Şmig ${ }^{12}$.

Tot în legătură cu caracterul întâmplător al descoperirilor se cere a fi consemnat faptul că doar trei dintre acestea pot fi raportate la un anume context arheologic: falera de la Vărşand, ce poate fi pusă în relație cu aşezarea culturii Otomani din punctul „Cetatea de pământ” aflată în perimetrul localităţii arădene menționate; cele două falere de la Beba Veche, incluse în inventarul funerar al unei necropole; în fine, falera din tezaurul descoperit întâmplător - nu ca rezultat al unor săpături arheologice - în cunoscuta aşezare „Şanţul Mare" de la Pecica. Mai trebuie menționat şi faptul că şase dintre descoperiri au inclus doar falere găsite izolat, celelalte patru constituind cunoscute tezaure - Şmig, Pecica-Rovine, Ostrovu Mare, Țufalău - în care falerele s-au aflat împreună cu alte tipuri de podoabe sau însemne de rang.

Din punct de vedere morfologic falerele de aur descoperite în România se ordonează în două grupe: ovale - variantă reprezentată doar de exemplarele de la Beba Veche; şi circulare - variantă care include toate celelalte falere cunoscute până în prezent. După profilul pieselor se pot deosebi două tipuri: plate - exemplarele de la Beba Veche; şi convexo-concave piesele din celelalte descoperiri. Ultimului tip de falere îi este caracteristică şi prezența unui umbo central mai mult sau mai puțin

\footnotetext{
${ }^{11}$ Dorin Popescu, op. cit., p. 247; Radu Florescu, în op. cit., p. 348; Amália Mozsolics, op. cit.,p. 54-55.

${ }^{12}$ Compară Amália Mozsolics, op. cit., pl. $3 / 11 \mathrm{cu}$ pl. 15/9-10 şi pl. 16/2.
}

proeminent, cu diametrul mai redus sau, dimpotrivă, mai mare. Se pot observa şi două modalități diferite de tratare a marginilor: la acelaşi nivel cu piesa sau întoarse, trase în jos.

La toate piesele, indiferent de tipul căreia îi aparțin, se constată acelaşi sistem de prindere: prin perforații circulare marginale, dispuse diametral. Excepție face falera de la Pecica, ale cărei orificii (două) nu sunt marginale, ci plasate în câmp. În fine se mai cere precizat că pe falerele de la Beba Veche cele patru perforații marginale de prindere sunt grupate câte două la extremitățile diametrului mare.

Indiferent de grupa în care se înseriază, toate falerele de aur au suprafețele ornamentate, unele $\mathrm{cu}$ decor mai simplu (exemplarele de la Beba Veche), altele cu decor mai variat sau mai complex. Cel mai bogat ornamentate sunt piesele de la Săcuieni, Ostrovu Mare, Grăniceri şi falerele mari de la Țufalău.

Tehnica în care au fost lucrate falerele este în prezent bine surprinsă, corect definită. Referindu-se la falerele din tezaurul de la Ostrovu Mare, Dorin şi Valeria Popescu au deosebit două etape principale de lucru: decuparea dintr-o foaie de aur a formei dorite şi realizarea decorului reliefat, prin înțepare sau incizare cu un vârf de bronz, pe reversul foii de aur, obținându-se pe avers pozitivul motivelor ${ }^{13}$. La rândul său, Radu Florescu a menționat ca procedee de prelucrare artistică a aurului frecvent utilizate, ciocănirea ,au repoussé" şi ponsonarea, ele fiind mai adecvate calităților de maleabilitate şi ductibilitate ale acestui metal ${ }^{14}$.

Spre deosebire de falerele din bronz care au circulat în epocă şi care au putut fi clasificate în doar trei grupe pe criteriul dimensiunii lor, cele din aur nu oferă posibilitatea unei asemenea grupări. Motivația se regăseşte într-o diversitate extremă a mărimii pieselor, într-o variație s-ar putea spune - aleatorie a dimensiunii acestora. Putem totuşi consemna că cele mai

\footnotetext{
${ }^{13}$ Dorin şi Valeria Popescu, Asupra tezaurului de aur de la Ostrovul Mare, în SCIV, VI, 3-4, 1955, p. 865866.

${ }^{14}$ Radu Florescu, în op. cit., p. 151, 221.
} 
mici piese (9 exemplare, descoperite la Pecica, Țufalău şi Transilvania-localitate necunoscută) au diametrele între 1,28 şi $2,90 \mathrm{~cm}$; cele mai mari - falerele de la Grăniceri - au diametre variind între 13 şi $13,6 \mathrm{~cm}$; şi că dintre celelalte 68 falere, cu diametrul între 3 şi $9 \mathrm{~cm}$, mai numeros este grupul pieselor având între 3 şi $4 \mathrm{~cm}$ (41 exemplare, din tezaurele de la Şmig şi Ostrovu Mare). Corespunzător acestei diversități a dimensiunilor, greutatea pieselor este şi ea extrem de variată: între 0,21 şi 85,55 gr, cu menţiunea că 23 exemplare - descoperite la Adoni, Beba Veche, Vărşand, Şmig, Săcuieni şi Ostrovu Mare - au greutăţi situate între 7 şi 28,5 gr.

Câteva considerații se cer consemnate în legătură cu funcționalitatea falerelor de aur din epoca bronzului de pe teritoriul României. Majoritatea cercetătorilor au considerat că aceste artefacte au constituit preponderent podoabe de veşmânt. Spre exemplu, Dorin Popescu a notat că falerele ,serveau la împodobitul hainelor, pe care erau prinse sau cusute" ${ }^{15}$. O estimare similară regăsim la Radu Florescu, care a făcut referiri exprese la câteva descoperiri, apreciind falerele ca aplice vestimentare (Adoni), garnituri de veşmânt (Şmig, Ostrovu Mare) sau pectorali (Grăniceri) ${ }^{16}$. Trebuie consemnată, în fine, opinia Amáliei Mozsolics care, referindu-se la descoperirea de la Țufalău, a prezentat falerele din acest tezaur ca piese de harnaşament - „discuri de şa" ${ }^{17}$.

Reținând aceste consideraţii, consemnăm în cele ce urmează şi câteva puncte de vedere proprii.

În epoca bronzului falerele de aur de pe teritoriul țării noastre au fost folosite cu precădere ca podoabe de veşmânt sau de corp. Un prim argument în acest sens credem că îl constituie descoperirea de la

\footnotetext{
15 Dorin Popescu, op. cit., p. 205.

${ }_{16}$ Radu Florescu, în op. cit., p. 22, 46, 253-254, 262.

17 Amália Mozsolics, op. cit., p. 54.
}

Beba Veche, unde o faleră de aur a fost găsită într-un mormânt de inhumație, iar o a doua piesă „la o distanţă de $3 \mathrm{~m}$. de un mormânt” (probabil deranjat, falera fiind în legătură cu el). Utilizarea falerelor de aur ca podoabă de veşmânt sau de corp este argumentată şi de sistemul de prindere a lor: perforații circulare marginale, dispuse diametral, ce serveau fie pentru fixarea pieselor pe veşminte, fie pentru suspendarea lor la gât cu şnur textil sau fir metalic (în cazul pectoralelor). Se impune precizarea că până acum nu s-au descoperit pe teritoriul României falere de aur - datând din epoca bronzului - prevăzute cu nituri de prindere, situație înregistrată mai târziu, pe falerele de argint (piesele de harnaşament din tezaurul de la Lupu, spre exemplu) proprii civilizației geto-dace din a doua epocă a fierului. De asemenea, nici una dintre falerele de aur descoperite până în prezent nu este prevăzută cu gaică sau toartă de fixare, fapt ce le delimitează de falerele turnate în bronz, care au circulat în epocă şi care sunt prezentate - îndreptățit - ca piese de harnaşament. Acelaşi detaliu morfologic diferențiază falerele de aur de alte podoabe sau accesorii de veşmânt - butoni, nasturi prevăzute cu gaică sau toartă de prindere. Precizarea din urmă se impune deoarece în literatura de specialitate s-au înregistrat ezitări şi chiar erori în aprecierea unora dintre piese. Astfel, de exemplu, prezentând descoperirea de la Pecica-Rovine, Dorin Popescu a notat: "Mica faleră (sau nasture) este bombată şi are un diametru de numai 1,2 cm"18. Este adevărat că acest exemplar constituie unica faleră cunoscută la noi având perforațiile de prindere (două) plasate nu marginal, ci în câmp, fapt care - împreună cu dimensiunea - ar putea sugera posibilitatea definirii piesei ca nasture. Credem însă că fragilitatea obiectului în discuție - ca de altfel a tuturor falerelor, lucrate din foaie subțire de aur, de regulă bombată - nu permitea utilizarea lui ca accesoriu vestimentar destinat încheierii veşmintelor, acesta din urmă trebuind să posede o anumită robustețe, însuşirea de a fi rezistent. Din aceleaşi considerente nu putem accepta nici prezentarea ca „tutuli” a cinci dintre falerele

${ }^{18}$ Dorin Popescu, op. cit., p. 206. 
tezaurului de la Țufalău, înregistrate ca atare în evidențele Muzeului Național din Budapesta. Avem în vedere şi o definire a tutulilor formulată de Tiberiu Bader „discuri...care în general au o formă conică, prevăzute la vârf cu buton conic sau sferic, toate au o gardină lată, iar în interior o tortiță" ${ }^{\prime 19}$ - care permite sesizarea evidentelor diferențe de ordin morfologic dintre cele două tipuri de podoabe.

În literatura de specialitate apare unanimă aprecierea că falerele au avut cu deosebire rol decorativ. În acest sens observăm că în patrimoniul orfevrăriei din epoca bronzului piesele în discuție constituie tipul de obiect întotdeauna ornamentat, decorul desfăşurându-se deseori - pe aproape întreaga suprafață a piesei. Motivele geometrice şi spiralice prezente pe toate falerele, combinate uneori în compoziții complexe, elaborate, sau ansamble decorative cu simbolistică solară au asigurat acestor artefacte incontestabile valențe estetice, individualizându-le în repertoriul obiectelor de podoabă din epocă. Sintaxa decorativă după care sunt ordonate motivele ornamentale este cu deosebire radiară, fapt determinat, desigur, de forma circulară sau ovală a falerelor. Conform regulilor - nescrise! - proprii acestei sintaxe, fiecare compoziție este alcătuită „prin dispunerea motivelor de-a lungul mai multor axe ordonate ca razele unui cerc, în raport cu un centru comun" ${ }^{20}$. Simbolistica solară a unei asemenea ornamentări este evidentă și a fost subliniată în literatura de specialitate $^{21}$.

În fine, să remarcăm că valoarea intrinsecă şi însuşirile estetice deosebite au conferit falerelor nu numai functia decorativă dar şi atributele proprii unor artefacte destinate actului ceremonial, atât de frecvent - cum se știe - în existența colectivităților omeneşti preistorice. Şi tot în legătură cu semnificația falerelor să reținem că exemplare de mari dimensiuni şi somptuos decorate (cele de la Săcuieni,

19 Tiberiu Bader, Epoca bronzului in nord-vestul Transilvaniei, Bucureşti, 1978, p. 106.

${ }^{20}$ Radu Florescu, în op .cit., p. 310.

21 Loc. cit.
Grăniceri, Ostrovu Mare) puteau reprezenta însemne de distincție socială. Astfel de estimări au formulat Amália Mozsolics, care a apreciat că falerele mari erau „cu siguranță pectorale, respectiv însemne de rang" 22 şi Radu Florescu, care referindu-se la garniturile vestimentare de la Şmig şi Ostrovu Mare a subliniat că ele serveau ,şi ca însemne simbolice, rituale sau sociale, marcând poziția purtătorilor lor" ${ }^{, 23}$.

Mai mulți cercetători care au studiat falerele din bazinul carpato-dunărean au pus aceste obiecte de podoabă în relație cu piese similare din Grecia miceniană. În acest sens s-au făcut trimiteri la falerele de aur descoperite în mormintele "cu groapă simplă" de la Mykene, datate în secolul al XVI-lea a. Chr., apreciindu-se că ele - mai ales pe baza ornamentării - ar putea constitui prototipuri pentru exemplarele din România ${ }^{24}$. Făcând o referire concretă, Amália Mozsolics a estimat că unele dintre falerele de la Țufalău "amintesc de forme miceniene, deşi, potrivit analizelor spectrografice, sigur nu sunt importuri" ${ }^{25}$. Neîndoielnic, o influență a civilizației egeice asupra celei carpatodunărene a constituit în epoca bronzului $o$ realitate care nu trebuie trecută cu vederea. Se poate accepta fără rezerve că în decorul unor falere de la Țufalău sau de la Ostrovu Mare se întrevede o inspirație miceniană. Totuşi, nu se poate să nu se remarce că cele dintâi discuri-falere de metal apar în eneolitc, când se trece la exploatarea şi prelucrarea cuprului şi aurului. Pentru spațiul carpatodanubiano-balcanic - unde civilizația eneolitică a cunoscut manifestări de apogeu dovezi incontestabile sunt: discul conicaplatizat, de aramă, decorat în tehnica "au repoussé" cu şir de puncte în relief, descoperit în aşezarea Cucuteni A de la Hăbăşeşti (județul Iaşi) ${ }^{26}$; discurile convexe

\footnotetext{
22 Amália Mozsolics, op. cit., p. 30.

${ }^{23}$ Radu Florescu, în op. cit., p. 46.

24 Dorin Popescu, op. cit., p. 237.

25 Amália Mozsolics, op. cit., p. 28.

${ }^{26}$ Hăbăşseşti, monografie arheologică, Bucureşti, 1954, p. 435-439, fig. 41/1, pl. CXXIV/1.
} 
prevăzute cu perforații, din depozitul de podoabe eneolitice de la Brad (județul Bacău) - două exemplare din aur (cu diametrele 6,3/5,9 $\mathrm{cm}$ şi 4,8/4,6 cm), unul dintre ele decorat cu şir perlat marginal şi două din aramă, neornamentate (cu diametrele 3,2 şi respectiv $5,3 \mathrm{~cm})^{27}$; numeroasele aplice discoidale, de aur, prevăzute pe margini cu orificii de prindere, descoperite în mormintele nr. 1, 36, 41, 43 din marea necropolă eneolitică de la Varna (Bulgaria), aparținând complexului cultural Gumelnița-Kodja Dermen-Karanovo $\mathrm{VI}^{28}$; aplicele discoidale convexe incluse în tezaurul cu obiecte de aur de la Gyoma (Ungaria) $^{29}$ din perioada eneolitică finală, similare pieselor de la Varna. O eventuală evoluție către falerele din perioada mijlocie a epocii bronzului carpato-dunărean apare marcată de piesa (butonul) în formă de calotă emisferică, cu două orificii de prindere, şi de mica faleră de aur cu decor punctat în relief, descoperite în aşezarea "Şanțul Mare" de la Pecica-Rovine (județul Arad), ambele datate în Bronzul timpuriu ${ }^{30}$. Se poate astfel admite că impulsurile venite din aria şi civilizația egeeană asupra ariei şi civilizației nord-trace, carpato-dunărene stimulând aici, între altele, şi realizarea unor falere de aur splendid decorate, de inspirație miceniană - s-au grefat pe o experiență şi o tradiție locale, îndelungate.

Realizarea falerelor de aur din epoca bronzului, de pe teritoriul României, poate fi atribuită cu certitudine populaţiilor nordtrace de aici. Argumente - curent invocate în literatura de specialitate - sunt: proveniența transilvană a aurului utilizat fapt probat de analiza spectrală a două fragmente de falere de la Țufalău, comparată cu analiza spectrală a unor probe de minereu extrase din perimetre aurifere

\footnotetext{
27 Vasile Ursachi, în Carpica, XXIII, 1992, p. 55-57.

28 Le premier or de l'humanité en Bulgarie, 5e millénaire, Edition de la Réunion des musées nationaux, Paris, 1989, p. 112, 130, 136, 142-143. 29 Doina Leahu, în Buletinul Muzeului "Teohari Antonescu", an III, nr. 5-6, Giurgiu, 2000, p. 205 şi urm. 30 Dorin Popescu, op. cit., p. 205-206.
}

intracarpatice ${ }^{31}$; de asemenea, prezența unor segmente de aur brut în componența tezaurelor de la Ţufalău şi Şmig ${ }^{32}$; în fine, dar mai ales, încadrarea certă a ornamentelor de pe falerele de aur din România în repertoriul motivelor ornamentale şi normelor sintaxei decorative proprii ceramicii culturilor Wietenberg, Otomani şi Gârla Mare. Menționarea tiparului de podoabă descoperit în stațiunea arheologică complexă de pe malul lacului Tei din Bucureşti ${ }^{33}$ ca posibil argument pentru realizarea locală a unor falere de aur de la Țufalău - aşa cum a estimat Dorin Popescu ${ }^{34}$ - nu se mai poate astăzi susține. Tiparul în discuție nu aparține culturii Tei din epoca bronzului; este târziu, databil în secolul VI p. Chr., fiind de tip bizantin și aparține locuirii de tip CiurelIpoteşti-Cândeşti, din stațiunea $\mathrm{Tei}^{35}$.

$\mathrm{Cu}$ totul caracteristică şi definitorie pentru apartenența culturală a acestor obiecte de podoabă este ornamentarea lor. Motivele decorative şi sintaxa ornamentală care se pot observa constituie elemente pe baza cărora piesele analizate pot fi atribuite cultural şi încadrate cronologic cu suficientă certitudine.

Principalele motive decorative sunt următoarele: cercul - singular, multiplicat, poziționat concentric (Beba Veche, Săcuieni, Grăniceri, Ostrovu Mare, Țufalău, Vărşand); unda etruscă circulară (Ostrovu Mare, Săcuieni, Țufalău, Vărșand); volute - simple, duble - în "C", în "S" sau "cârcei" (Grăniceri, Ostrovu Mare); cârligul spiralic (Grăniceri, Ostrovu Mare); triunghiul (Beba Veche); triquetrul (Şmig); pelta (Grăniceri); rozeta (T,ufalău); torsada (Ostrovu Mare); chenarul circular lobat (Vărşand, Ostrovu Mare).

\footnotetext{
31 Amália. Mozsolics, op. cit., p. 28, 63 şi urm. (analize efectuate de Axel Hartmann în Laboratorul de la Stuttgart)

32 Amália. Mozsolics, în Acta Archaeologica, 1952, II, fasc. 1-3, p. 29 .

33 Dinu V. Rosetti, Civilizația tip București - Die Bukaresterkultur, 1936, pl. IX, 49, 50.

${ }^{34}$ Dorin Popescu, op. cit., p. 249, n. 6.

35 Cf. Victor Teodorescu, în SCIV, 15, 1964, 4, p. 485 şi urm.
} 
Apropieri stilistice între decorul falerelor de aur de pe teritoriul României şi ornamentarea ceramicii unora dintre culturile epocii bronzului de aici au fost semnalate de mult. Remarci pertinente erau, astfel, consemnate încă în primii ani ai secolului XX, de către arheologul maghiar Márton Lájos ${ }^{36}$ - într-o vreme în care totuşi numărul restrâns şi acuratețea ştiinţifică a descoperirilor arheologice erau departe de a susține comparații detaliate, interpretări aprofundate. Ulterior, înregistrându-se progrese în cunoaşterea trăsăturilor caracteristice şi evoluției diferitelor tipuri de cultură create în epoca bronzului de tracii carpato-dunăreni, a devenit posibilă şi clarificarea apartenentei culturale a discurilor-falere.

Dacă la începutul deceniului al treilea Gordon Childe ezita să apropie falerele de la Beba Veche de decorul ceramicii descoperite la Periam şi Pecica ${ }^{37}$, în 1932 Ion Nestor și în 1937 J. Banner se pronunțau decis în acest sens ${ }^{38}$. La mijlocul secolului, Dorin Popescu, încercând să răspundă întrebării «cărei culturi îi va fi aparţinut tezaurul de la Țufalău?», avea în vedere cultura Wietenberg, sau se gândea "eventual la cultura Tei" ${ }^{39}$. Tot pe atunci, acelaşi cercetător atribuia falerele de la Ostrovu Mare - de asemenea pe baza studierii decorului - culturii de tip Gârla Mare $^{40}$.

În prezent încadrarea culturală a pieselor de podoabă pe care le analizăm are certitudine, bazându-se pe un fond cuprinzător şi caracteristic de mărturii ceramice, care provin din ariile, bine delimitate, ale unor tipuri de cultură riguros studiate. Asemănărilor dintre motivele decorative de pe obiectele de metal şi vasele ceramice li se adaugă un alt criteriu de stabilire a apartenenței: situarea locului

\footnotetext{
36 Márton L., în Archaeologya Értesitö, 1909, p. 405 şi urm.

37 Gordon V. Childe, The Danube in Prehistory, Oxford, 1923, p. 216-219.

38 Ion Nestor, Der Stand..., p. 84; J. Banner, în Dolgozatok, XIII, 1937, p. 232 şi urm.

39 Dorin Popescu, op. cit., p. 249.

40 Dorin şi Valeria Popescu, op. cit., p. 871, 873.
}

de descoperire a falerelor în aria unei culturi sau alteia.

\section{Astfel:}

Cele două falere din necropola de la Beba Veche pot fi atribuite culturii PeriamPecica (Mureş), ținând seamă că locul descoperirii se situează cert în aria culturii cu acest nume şi luând în considerare că triunghiurile care ornează discurile de aur, ca şi cercurile punctate, se regăsesc ca motive decorative pe ceramica descoperită la Pecica (județul Arad) şi Periam (județul Timişs) ${ }^{41}$. Tot astfel, trebuie atribuite culturii Sighişoara-Wietenberg falerele (şi întregul tezaur) de la Şmig, deoarece locul descoperirii se plasează în aria culturii menționate, şi pentru că decorul întâlnit pe unele dintre falere - segmentarea câmpului cercului în trei sectoare, prin fascicule sau benzi slab arcuite, care pleacă din centru (umbo) şi au terminații pe circumferință apare frecvent pe ceramica Wietenberg ${ }^{42}$. Culturii Wietenberg trebuie să-i fie atribuite şi falerele (şi de asemenea întreg tezaurul) de la Țufalău, unda etruscă circulară care decorează piesele discoidale mari constituind motiv întru totul caracteristic pentru ceramica culturii răspândite în podişul transilvan ${ }^{43}$. De altfel, descoperirea se plasează, şi ea, în aria Wietenberg. În aceeaşi arie şi acelaşi tip de cultură se situează cele trei falere de la Săcuieni, decorul lor având cele mai bune analogii în ceramica Wietenberg: piesa ornamentată cu undă etruscă circulară are corespondență în motivistica vaselor din lut ars, întregi sau fragmentare, descoperite la Băgău (județul Alba), Band (județul Mureş), Deva (județul Hunedoara), Sibişeni (județul Alba), Sighişoara (județul Mureş) etc. ${ }^{44}$; exemplarul ornamentat cu undă etruscă din şapte lobi cvasi-semilunari înlănțuiți, închizând un "umbo" circumscris de două cercuri concentrice strâns alăturate - având o perfectă analogie în decorul unei mici

\footnotetext{
41 Dorin Popescu, Die frühe und mittlere Bronzezeit in Siebenbürgen, Bucureşti, 1944, p. 61, fig. 18/8, pl. $\mathrm{IV} / 2$.

${ }^{42}$ Nikolaus Boroffka, Die Wietenberg-Kultur. Ein Beitrag zur Erforschung der Bronzezeit in Südosteuropa, Bonn, 1994, Teil 2, pl. tipol. 19/4.

${ }^{43}$ Ibidem, pl. tipol. 15-16.

${ }^{44}$ Ibidem, pl. 4/10, 8/3, 68/4, 123/4-6, 129/2.
} 
străchini descoperită la Cipău (județul Alba) $)^{45}$; iar dubla undă etruscă "cu spini", care ornamentează cea de a treia faleră, fiind de asemenea un motiv întâlnit în cultura Wietenberg ${ }^{46}$. Exemplificareaargumentare poate fi adusă pentru aproape toate falerele de aur de pe teritoriul României. Ne vom mai referi doar la două cazuri: piesa descoperită în aşezarea culturii Otomani de la Vărşand (județul Arad), despre care Vladimir Dumitrescu a apreciat că decorul ei "este frecvent întâlnit şi în ornamentarea ceramicii culturii Otomani" ${ }^{47}$; şi falerele din tezaurul de la Ostrovu Mare (județul Mehedinți), descoperite în aria culturii Gârla Mare, în ale căror ornamente au fost identificate motive - volutele în "C", capetele de volute afrontate, spiralele fugătoare - proprii, de asemenea, decorului ceramicii culturii mentionate $^{48}$.

Se constată, este adevărat, şi situații deosebite - doar aparent mai complicate cum sunt falerele de la Grăniceri (județul Arad). Descoperirea acestora se situează în aria culturii Otomani, dar se poate observa că motivele ornamentale şi sintaxa decorativă proprii pieselor se regăsesc mai frecvent şi în ipostaze mai apropiate în ariile culturilor Wietenberg, Gârla Mare şi Cruceni-Belegiš, contemporane - integral sau parțial - culturii Otomani ${ }^{49}$. Se adaugă apoi elementele antropomorfe şi zoomorfe - două siluete umane şi doi cai afrontați de pe falera păstrată fragmentar, precum şi cele două păsări afrontate de pe falera ornamentată cu perechi de volute pelta. Desigur, astfel de reprezentări nu sunt constatate pe celelalte falere de aur de pe teritoriul României, fapt ce a determinat pe unii cercetători să plaseze piesele în discuție într-un cadru cronologic mai târziu, apropiat începutului primei epoci a fierului.

\footnotetext{
${ }^{45}$ Ibidem, pl. 51/4.

46 Ibidem, pl. tipol. 16/1.

47 Vladimir Dumitrescu, op. cit., p. 401.

${ }^{48}$ Dorin şi Valeria Popescu, op. cit., p. 873.

49 Pentru comparație, cf. Vladimir Dumitrescu, Necropola de incinerație din epoca bronzului, de la Cârna, Bucureşti, 1961, pl. CXXXV, 238, CXXXVI, 325; Marian Gumă, Epoca bronzului în Banat, Timişoara, 1997, pl. LXXXI, C6.
}

Credem însă că nu trebuie omise reprezentarea zoomorfă şi cele antropomorfe - schematizate - gravate pe toporul de aur cu ceafa prelungită din tezaurul de la Țufalău, datat de către toți specialiștii în perioada mijlocie a epocii bronzului. Pot fi aduse în discuție şi recipientele cu protome aviforme sau statuetele în formă de pasăre din cultura Gârla Mare, care atestă utilizarea acestui motiv - evident, într-o manieră diferită de reprezentare plastică - tot în epoca bronzului.

Încadrarea cronologică - relativă şi absolută - a falerelor de aur descoperite pe teritoriul României a preocupat, de-a lungul timpului, în mod constant cercetarea arheologică.

Exceptând unele încadrări care s-au dovedit a fi sigur eronate - datarea tezaurului de la Țufalău de către Paul Reinecke în jurul anilor 700 a. Chr. (în Hallstatt mijlociu!) ${ }^{50}$, sau datarea de asemenea în prima epocă a fierului a pieselor de la Beba Veche, admisă de Vasile Pârvan ${ }^{51} \quad-$ majoritatea cercetătorilor au plasat falerele de aur în epoca bronzului, cu precădere în perioada ei mijlocie. Explicit, Dorin Popescu a afirmat: "...este foarte probabil că cea mai mare parte a falerelor ornamentate de aur din Transilvania - cu excepția, poate, numai a celor de la Şmig - trebuie datată în perioada mijlocie a epocii bronzului. Cele de la Şmig ne arată, în cazul în care tezaurul trebuie datat la sfârşitul epocii, că ele au avut o viață lungă, fiind păstrate din generație în generație" ${ }^{52}$. Studiul Amáliei Mozsolics amplu, aprofundat, bine argumentat cu ajutorul unor multiple şi elocvente comparații cu descoperiri de bronzuri din Transilvania şi Ungaria - a fost de natură a consolida o asemenea poziție. Iar progresele înregistrate în cunoaşterea culturilor SighişoaraWietenberg şi Otomani - în evoluția cărora sunt în prezent identificate mai multe faze,

\footnotetext{
50 În Germania, 1925, p. 52; încadrare corectată de savantul german însuşi, în Germania, 28, 1944-1950, p. 272.

51 Vasile Pârvan, op. cit., p. 342.

${ }^{52}$ Dorin Popescu, op. cit., p. 211.
} 
apărând evidentă legătura decorului falerelor de aur cu fazele de maximă afirmare (Wietenberg III, Otomani II) ale acestor culturi - asigură premize pentru o încadrare "strânsă" a podoabelor analizate. În această privință, ca exemplificare, menționăm doar că identificarea similitudinilor dintre decorul falerelor de la Şmig şi motive proprii decorului ceramicii Wietenberg clarifică poziția în timp - în Bronzul mijlociu - a tezaurului.

Sintetizând datele de care dispunem acum, se poate admite încadrarea cronologică relativă a falerelor de aur analizate, astfel: exemplarele de la Beba Veche şi falera de la Pecica-Rovine către sfârşitul perioadei timpurii a epocii bronzului; toate celelalte falere - în perioada mijlocie a epocii bronzului, cu exceptia doar a celor trei piese descoperite la Grăniceri (Otlaca), care pot fi atribuite Bronzului târziu.

Încadrarea "absolută" - în ani solari a tuturor descoperirilor constituie, desigur, o operație mai dificilă, comportând şi riscul ridicat al comiterii erorilor. $\mathrm{Nu}$ deținem pentru moment date care să ofere certitudini, iar recenta propunere pentru o cronologie a epocii bronzului din România, avansată de Alexandru Vulpe ${ }^{53}$, invită la soluții uneori sensibil diferite de cele adoptate până acum. Pe parcursul ultimelor cinci decenii s-a conturat un acord deplin în a data falerele de aur - de fapt, tezaurele în care ele apar incluse - în intervalul secolelor XVI-XV a. Chr. Admisă de savanți de înaltă autoritate, cum sunt Vladimir Milojčičc ${ }^{54}$ sau Amália Mozsolics ${ }^{55}$, această încadrare a fost însuşită de toți ceilalți cercetători. În prezent însă propunerea profesorului Alexandru Vulpe de a situa perioada mijlocie a epocii bronzului din spațiul carpato-danubian între 2300$1600 / 1500$ a. Chr. ${ }^{56}$ invită la o "urcare" sensibilă a datării unora dintre falere.

\footnotetext{
${ }^{53}$ Alexandru Vulpe, în Memoriile Secției de Ştiințe Istorice şi Arheologice ale Academiei Române, seria IV, tomul XXI, 1996, p. 33-47.

${ }^{54}$ Vladimir Milojčič, în Germania, 28, 1944-1950, p. 272.

${ }_{55}$ Amália Mozsolics, Goldfunde..., p. 28-34.

${ }^{56}$ Alexandru Vulpe, op. cit., p. 46.
}

\section{Catalogul falerelor de aur din epoca bronzului descoperite pe teritoriul României.}

Falere de la Beba Veche

Beba Veche sat, comună, județul Arad. Sfârşitul perioadei timpurii a epocii bronzului.

În perimetrul localității au fost descoperite 26 morminte cu schelete chircite, într-unul dintre acestea aflându-se mai multe obiecte de aur: o placă uşor elipsoidală (faleră), 3 inele spiralice, câteva brățări sau verigi. $\mathrm{O}$ altă placă ornamentală a fost găsită mai târziu, la o distanță de $3 \mathrm{~m}$ de un alt mormânt. $\mathrm{Nu}$ se cunoaşte data descoperirilor.

\section{Faleră.}

Placă uşor elipsoidală; decor punctat alcătuit din două şiruri circulare pe contur şi două motive triunghiulare diametral opuse, flancate fiecare de câte două perforații mici circulare.

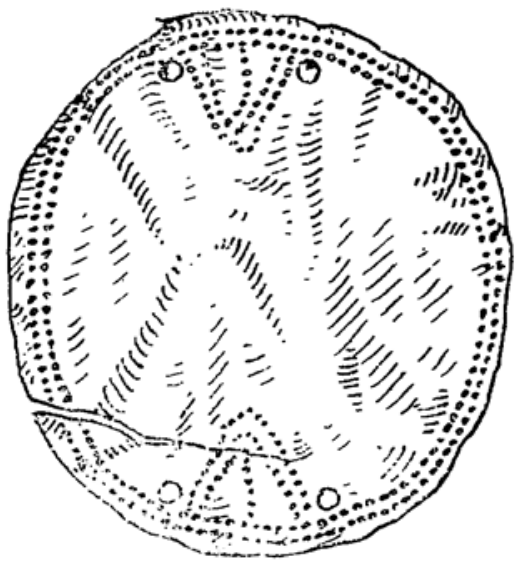

DM (după desen) $=$ cca. $5,5 \mathrm{~cm} ; \mathrm{Dm}=\mathrm{cca} .5,1 \mathrm{~cm}$; $\mathrm{G}=(?)$.

Muzeul Naţional din Budapesta, Ungaria.

\section{Faleră.}

Placă uşor elipsoidală; decor punctat comportând două şiruri circulare pe contur, două motive triunghiulare diametral opuse, un grup de 3 triunghiuri şi alte 3 motive triunghiulare plasate pe contur; 4 perforații mici, grupate câte două la extremităţile diametrului mare. Piesă fragmentară. 


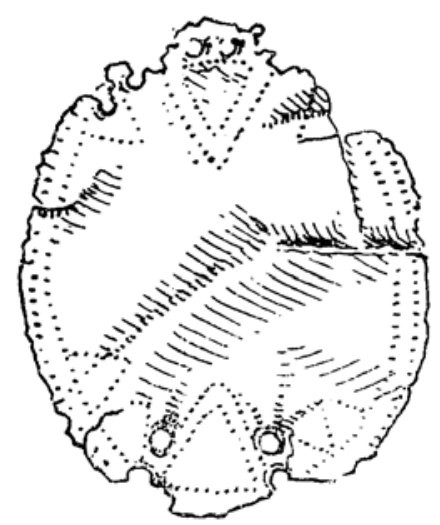

DM (după desen $)=$ cca. $5,0 \mathrm{~cm} ; \mathrm{Dm}=\mathrm{cca} .4,2 \mathrm{~cm}$; $\mathrm{G}=(?)$.

Muzeul Naţional din Budapesta, Ungaria.

\section{Faleră din tezaurul de la Pecica-Rovine}

Pecica sat, comună, județul Arad.

Sfârşitul perioadei timpurii a epocii bronzului.

În primăvara anului 1938 au fost aduse la Muzeul Național de Antichităţi din Bucureşti câteva obiecte de aur, descoperite întâmplător la Pecica-Rovine, pe malul drept al Mureşului. În timp ce lucra pe câmp un țăran a găsit, la locul numit "Prunişte", un vas ceramic cu două mânere, înalt de 10,2 cm, aparținând culturii Vatina. În vas se găseau mai multe obiecte mici: două scoici columbella, o mică faleră din aur, 48 de mărgele conice - unele strivite din acelaşi metal.

\section{Faleră.}

Disc convex cu "umbo" circumscris de două cercuri concentrice, perlate; două perforații dispuse diametral, în câmp.

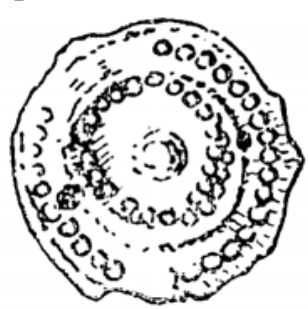

$\mathrm{DM}=1,32 \mathrm{~cm} ; \mathrm{Dm}=1,28 \mathrm{~cm} ; \mathrm{G}=0,21$ gr.

Muzeul Național de Istorie a României; inv. 11402.

\section{Falera de la Adoni}

Adoni sat, comuna Tarcea, județul Bihor.

Perioada mijlocie a epocii bronzului.

Descoperire întâmplătoare, fără dată.

\section{Faleră.}

Disc uşor bombat, cu "umbo" central circumscris în câmp de 7 cercuri concentrice în relief ciocănit; un şir marginal de perle ,au repoussé"; două perforații de prindere, dispuse diametral.

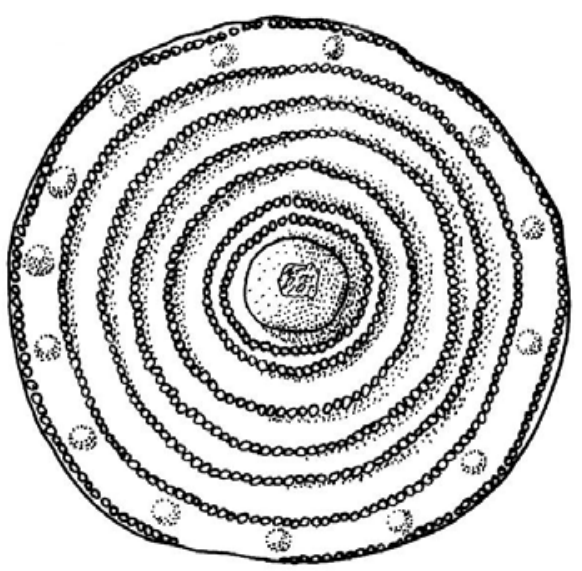

$\mathrm{D}=5,3 \mathrm{~cm} ; \mathrm{G}=7,34 \mathrm{gr}$.

Muzeul Naţional din Budapesta, Ungaria.

\section{Falera de la Vărşand}

Vărş̧and sat, comuna Pilu, județul Arad. Perioada mijlocie a epocii bronzului.

Piesa a fost găsită izolat, ante 1949, la „Movila dintre Vii” - aşezare de tip atol din epoca bronzului, cultura Otomani, fortificată cu circumvalație, cu locuințe de suprafață dispuse în şiruri circulare concentrice, în jurul unei piețe centrale. 


\section{Faleră.}

Disc convex cu "umbo" înconjurat de două cercuri concentrice ciocănite în relief; în câmp undă etruscă în relief ciocănit, mărginită de un dublu chenar continuu cu 5 lobi.

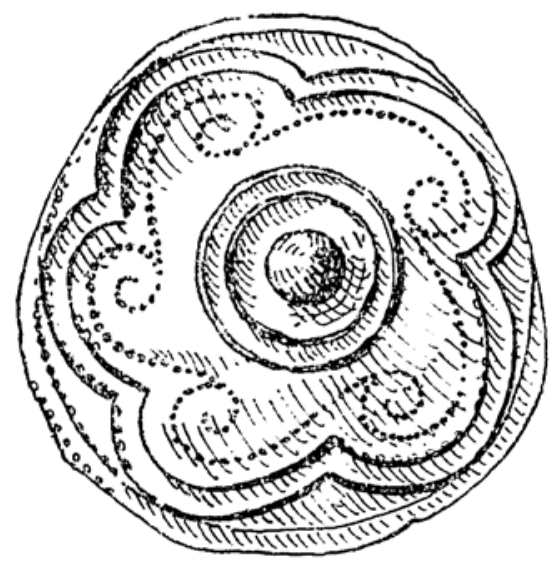

$\mathrm{D}=7,9-8,7 \mathrm{~cm} ; \mathrm{G}=(?)$.

Muzeul județean Arad.

\section{Faleră din Transilvania}

Transilvania, loc. nec.

Perioada mijlocie a epocii bronzului.

$\mathrm{Nu}$ se cunosc locul, data şi împrejurările descoperirii.

\section{Faleră.}

Disc bombat cu „umbo”, decorată cu două cercuri perlate "au repoussé" - unul central, celălalt pe contur; în câmp motiv floral cu 4 petale în cruce.

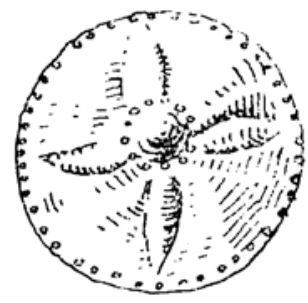

$\mathrm{D}($ după desen $)=2,9 \mathrm{~cm} ; \mathrm{G}=($ ?).

\section{Tezaurul de la Şmig}

Şmig sat, comună, județul Sibiu.

Perioada mijlocie a epocii bronzului.

Tezaurul a fost descoperit în 1880, în împrejurări insuficient clarificate. Se pare că el a fost găsit întâmplător de câțiva țărani, piesele fiind depozitate într-un vas de bronz, aşezat la rândul său într-un recipient ceramic. Ambele vase au fost sparte de țărani în momentul descoperirii. Tezaurul cuprindea, pe lângă cinci mărgele din argint, următoarele obiecte de aur: 26 discuri-falere de dimensiuni diferite; 18 inele de buclă, unele alcătuind un lanț; o brățară; două inele torsadate; 13 saltaleoni; 158 mărgele; un lingou oval din aur brut. O parte din piese (4 falere, brățara, cele două inele torsadate, 3 inele de buclă şi 4 mărgele -3 de aur şi una de argint) se păstrează în muzee din România, la Bucureşti şi la Cluj; celelalte piese (22 falere, 149 mărgele de aur şi 3 de argint, saltaleonii, lingoul de aur şi câteva fragmente din vasele de lut şi de bronz) au ajuns la Muzeul Național din Budapesta, în Ungaria. Câteva mărgele se pare că s-au pierdut.

\section{Faleră.}

Disc convex, cu "umbo" și decor în relief ciocănit; două cercuri concentrice în jurul umbonelui şi un alt cerc pe circumferință; între ele trei fascicule din câte trei şiruri perlate, dispuse la distanțe egale, arcuite oblic; în spațiile divizate câte trei proeminențe înşiruite paralel la circumferință; pe margine patru perforații dispuse simetric. 


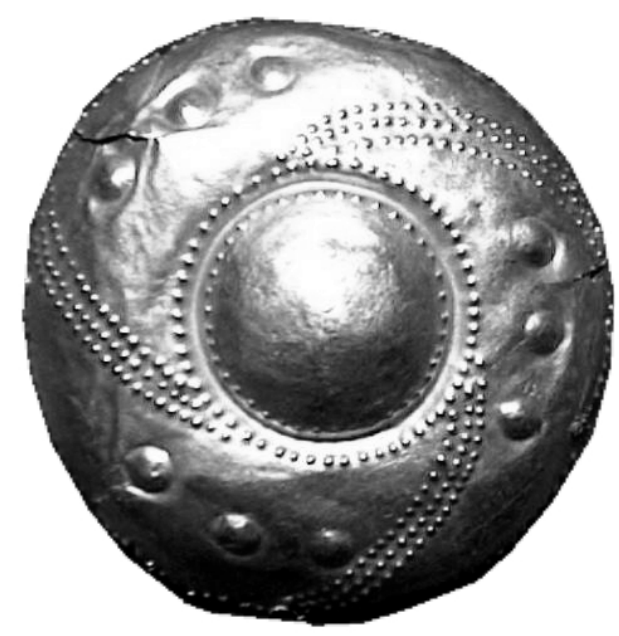

$\mathrm{D}=6,3 \mathrm{~cm} ; \mathrm{G}=9,40$ gr.

Muzeul Național de Istorie a României; inv. 47575 .

\section{Faleră.}

Disc convex cu "umbo" circumscris de cerc perlat; alt cerc pe circumferință; două perforații dispuse diametral pe margine.

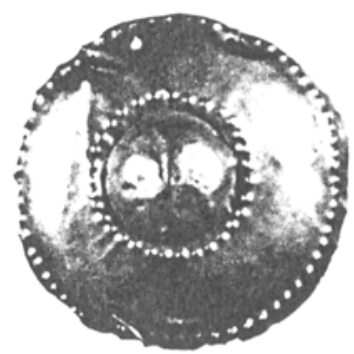

$\mathrm{D}=3,7 \mathrm{~cm} ; \mathrm{G}=4,50$ gr.

Muzeul Național de Istorie a României; inv. 47576.

\section{Faleră.}

Disc convex, cu "umbo" şi decor în relief ciocănit; două cercuri concentrice în jurul umbonelui şi un alt cerc pe circumferință; între ele trei fascicule din câte trei şiruri perlate, dispuse la distanțe egale, arcuite oblic; în spațiile divizate câte trei proeminențe înşiruite paralel la circumferință; pe margine patru perforații dispuse simetric.

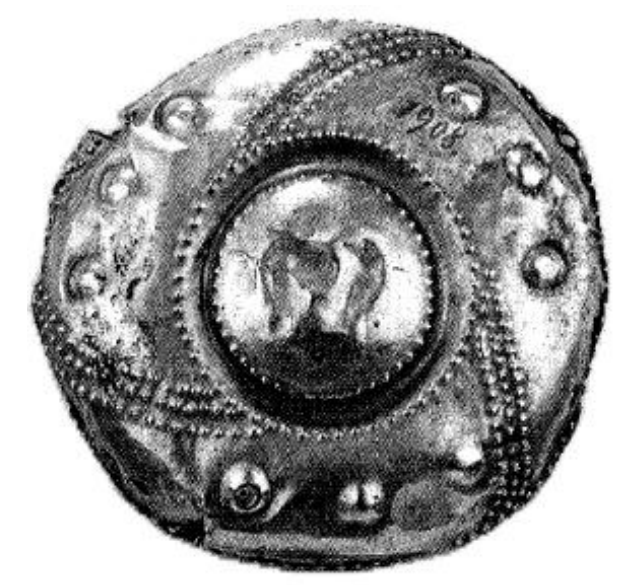

$\mathrm{D}=6,0 \mathrm{~cm} ; \mathrm{G}=9,85$ gr.

Muzeul de istorie a Transilvaniei, Cluj-Napoca; inv. P 81639 (1908).

\section{Faleră.}

Disc convex cu "umbo" circumscris de cerc perlat; alt cerc pe contur; între ele trei grupuri de câte trei proeminențe, înşiruite paralel la circumferință; două perforații marginale dispuse diametral.

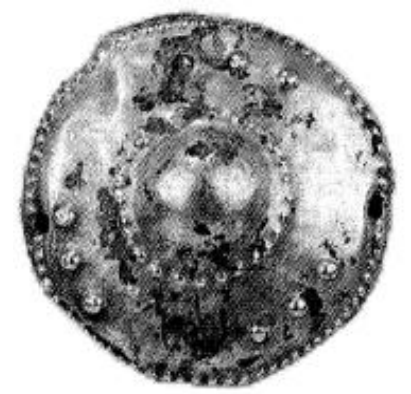

$\mathrm{D}=3,7 \mathrm{~cm} ; \mathrm{G}=4,7 \mathrm{gr}$.

Muzeul de istorie a Transilvaniei, Cluj-Napoca; inv. P 81640 (1909).

\section{Două falere.}

Disc convex cu "umbo" şi decor în relief ciocănit; în jurul umbonelui un cerc reliefat flancat de două cercuri perlate; un alt cerc pe circumferință; între ele trei fascicule din câte trei şiruri perlate, dispuse la distanțe egale, arcuite oblic; în spațiile divizate câte trei proeminențe înşiruite paralel la circumferință; pe margine patru perforații dispuse simetric. 


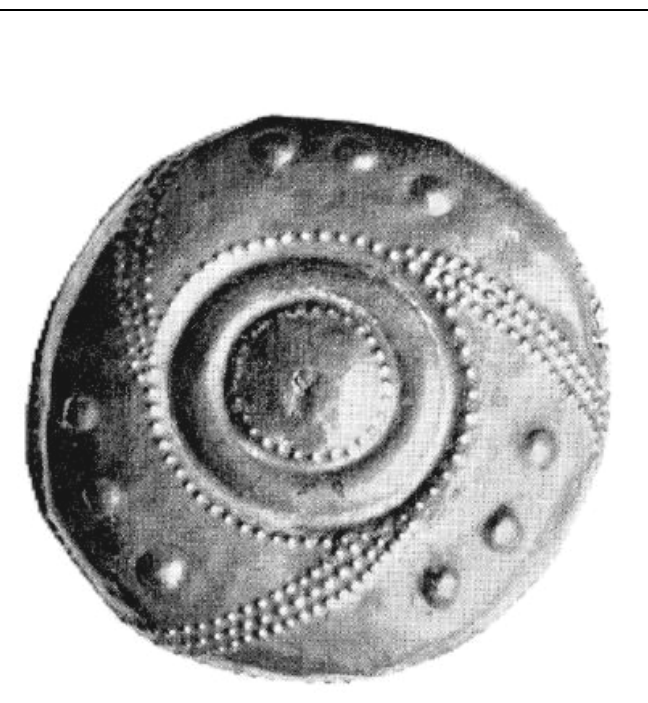

$\mathrm{D}=7,1 \mathrm{~cm}$ şi $7,2 \mathrm{~cm} ; \mathrm{G}=18,30 \mathrm{gr}$ şi $18,88 \mathrm{gr}$. Muzeul Naţional din Budapesta, Ungaria.

\section{Cinci falere.}

Disc convex, cu "umbo" şi decor în relief ciocănit; două cercuri concentrice în jurul umbonelui şi un alt cerc pe circumferință; între ele trei fascicule din câte trei şiruri perlate, dispuse la distanțe egale, arcuite oblic; în spațiile divizate câte trei proeminențe înşiruite paralel la circumferință; pe margine patru perforații dispuse simetric.

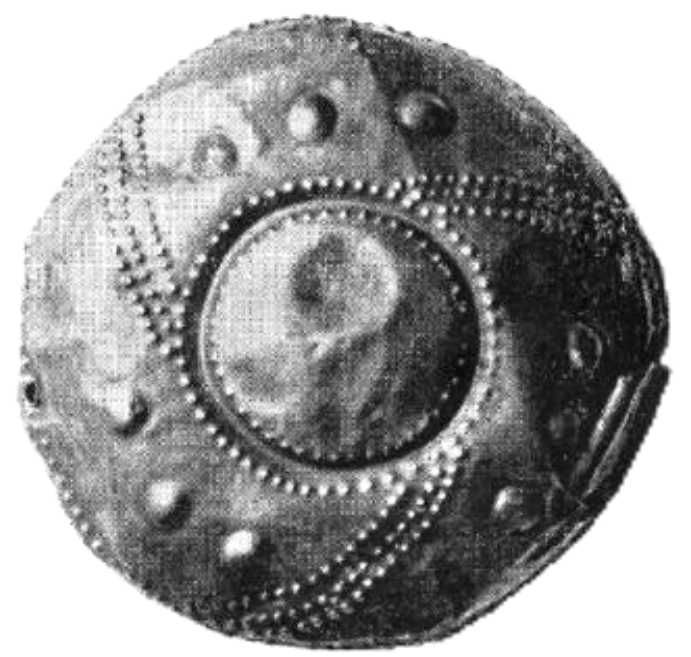

$\mathrm{D}=$ între 6,0 şi $6,2 \mathrm{~cm} ; \mathrm{G}=8,83 \mathrm{gr}, 10,84 \mathrm{gr}$, 9,33 gr, 10,77 gr, 10,59 gr.

Muzeul Naţional din Budapesta, Ungaria.

\section{Trei falere.}

Disc convex cu "umbo" circumscris de cerc perlat; alt cerc pe contur; între ele trei grupuri de câte trei proeminențe, înşiruite paralel la circumferință; două sau trei perforații dispuse marginal.

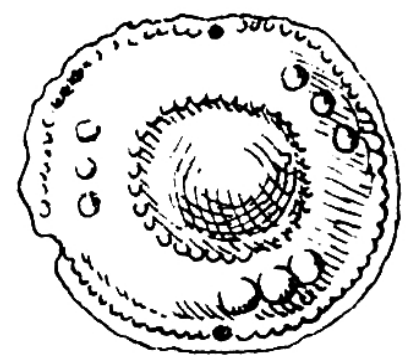

$\mathrm{D}=3,3 \mathrm{~cm}, 3,6 \mathrm{~cm}, 3,7 \mathrm{~cm} ; \mathrm{G}=3,61 \mathrm{gr}, 4,32 \mathrm{gr}$, 4,52 gr.

Muzeul Naţional din Budapesta, Ungaria.

\section{Trei falere.}

Disc convex cu „umbo" şi cerc perlat pe contur; trei grupuri de câte trei proeminențe înşiruite paralel la circumferință; două perforații marginale dispuse diametral.

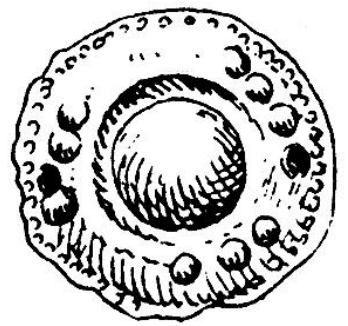

$\mathrm{D}=$ între $3,3 \mathrm{~cm}$ şi $3,4 \mathrm{~cm} ; \mathrm{G}=4,98 \mathrm{gr}, 4,65 \mathrm{gr}$, 4,43 gr.

Muzeul Naţional din Budapesta, Ungaria.

\section{Două falere.}

Disc convex cu „umbo" circumscris de cerc perlat; alt cerc pe circumferință; o piesă are două perforații marginale diametrale, cealaltă este fragmentară. 


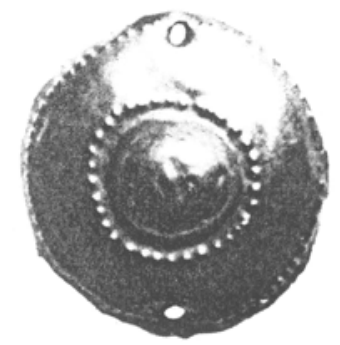

$\mathrm{D}=3,3 \mathrm{~cm}$ şi $3,5 \mathrm{~cm} ; \mathrm{G}=4,16 \mathrm{gr}$ şi $3,37 \mathrm{gr}$.

Muzeul Național din Budapesta, Ungaria.

\section{Faleră.}

Disc convex cu „umbo" şi cerc perlat pe circumferință; două perforații marginale dispuse diametral.

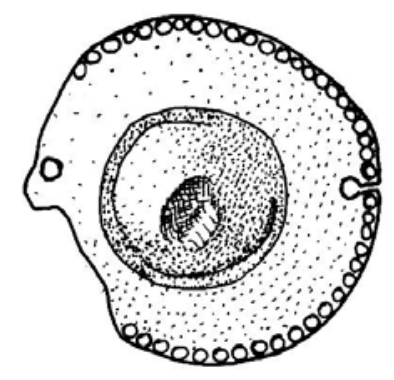

$\mathrm{D}=3,4 \mathrm{~cm} ; \mathrm{G}=4,3$ gr.

Muzeul Naţional din Budapesta, Ungaria.

\section{1. Şase falere.}

Disc convex, cu "umbo" şi decor în relief ciocănit; două cercuri concentrice în jurul umbonelui şi un alt cerc pe circumferință; între ele trei fascicule din câte trei şiruri perlate, dispuse la distanțe egale, arcuite oblic; în spațiile divizate câte trei proeminențe înşiruite paralel la circumferință; pe margine patru perforații dispuse simetric. Piese deteriorate.

$\mathrm{D}=$ între $6,0 \mathrm{~cm}$ şi $6,1 \mathrm{~cm} ; \mathrm{G}=9,12 \mathrm{gr}, 8,46 \mathrm{gr}$, $9,73 \mathrm{gr}, 8,98 \mathrm{gr}, 9,49 \mathrm{gr}, 9,07 \mathrm{gr}$.

Muzeul Național din Budapesta, Ungaria.

\section{Tezaurul de la Săcuieni}

Săcuieni sat, comună, județul Bihor.

Perioada mijlocie a epocii bronzului.

În anul 1927 a fost găsit întâmplător, într-o vie din satul Săcuieni, un tezaur alcătuit din 8 falere de aur. Dintre acestea se mai păstrează doar trei falere întregi şi un fragment dintr-o a patra.

\section{Faleră.}

Disc convex, cu decor ciocănit; undă etruscă din şapte lobi semilunari înlănțuiți, închizând un ,umbo" circumscris de două cercuri concentrice strâns alăturate; cerc marginal perlat; patru perforații dispuse diametral pe margine.

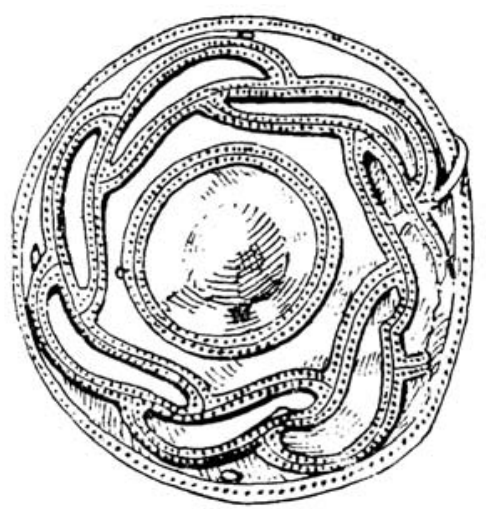

$\mathrm{D}=9,00 \mathrm{~cm} ; \mathrm{G}=27,95$ gr.

Muzeul Național de Istorie a României; inv. C 1744.

\section{Faleră.}

Disc convex cu decor ciocănit; „umbo" circumscris de două cercuri concentrice cu şir de puncte pe mediană; pe contur alte două cercuri cu şir de puncte median; în câmpul circular undă etruscă din volute duble în $\mathrm{S}$, înlănţuite; trei perforații marginale.

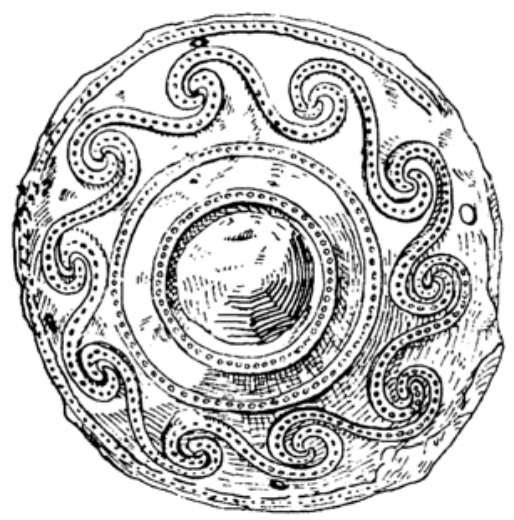

$\mathrm{D}=8,5 \mathrm{~cm} ; \mathrm{G}=28,50 \mathrm{gr}$.

Muzeul Național de Istorie a României; inv. C 1745. 


\section{Faleră.}

Disc convex cu decor ciocănit; "umbo" circumscris de bandă circulară din două cercuri concentrice închizând şir de unghiuri întrerupt; în câmpul circular două unde etrusce concentrice, din bandă de trei linii paralele flancând două şiruri de puncte; pe contur bandă din două cercuri concentrice închizând un şir de puncte; patru perforații marginale.

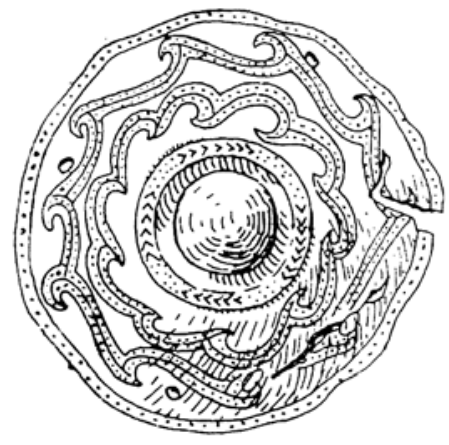

$\mathrm{D}=8,1 \mathrm{~cm} ; \mathrm{G}=23,72 \mathrm{gr}$.

Muzeul Naţional de Istorie a României; inv. C 1746.

\section{Tezaurul de la Țufalău}

Țufalău sat, comuna Boroşneu Mare, județul Covasna.

Perioada mijlocie a epocii bronzului.

În anul 1840 a fost descoperit întâmplător, pe drumul de țară dintre Ţufalău şi Brateş, un tezaur alcătuit din următoarele obiecte de aur: patru topoare (9, după informații mai vechi), mai multe falere (11-16; nu se cunoaşte numărul exact), 4 inele de buclă (ochiuri de lanț), aur brut. În prezent se mai păstrează un topor (alte trei fiind cunoscute doar din desene), 8 sau 13 falere întregi, fragmente din alte 3 falere şi, se pare, cele 4 inele de buclă.

\section{1. Şase falere.}

Disc uşor bombat cu "umbo" central circumscris de două cercuri concentrice din puncte reliefate; pe contur alte două cercuri concentrice din puncte în relief; două perforații de prindere dispuse diametral.

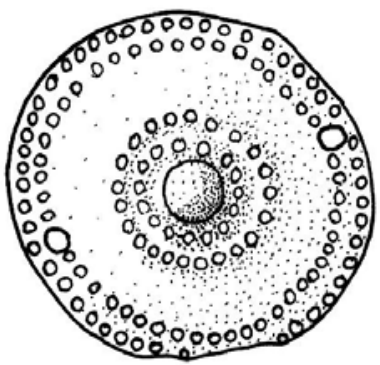

$\mathrm{D}=$ între $2,0 \mathrm{~cm}$ şi $2,1 \mathrm{~cm}$; $\mathrm{G}$ totală $=$ cca. $14 \mathrm{gr}$. Naturhistorisches Museum, Viena.

\section{Două falere.}

Disc cu "umbo" central; decor în relief ciocănit alcătuit dintr-o rozetă heptagonală cu vârfurile în volută, înscrisă în cerc.

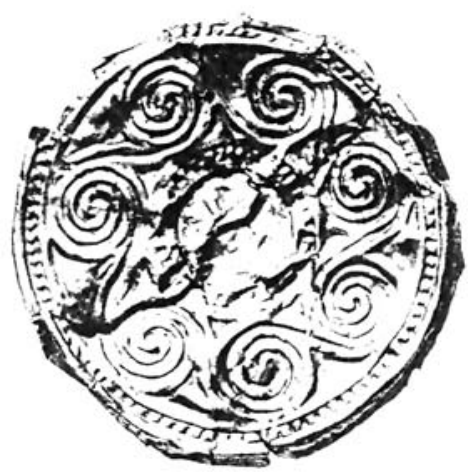

$\mathrm{D}=4,5-5,0 \mathrm{~cm} ; \mathrm{G}=3,47$ şi 4,00 gr.

Muzeul Naţional din Budapesta, Ungaria.

\section{Cinci falere.}

Disc uşor bombat, cu "umbo" central circumscris de cercuri concentrice din puncte reliefate: 3 falere cu câte un cerc în jurul umbonelui şi pe contur, 2 falere cu câte două cercuri dispuse asemenea; două perforații de prindere dispuse diametral.
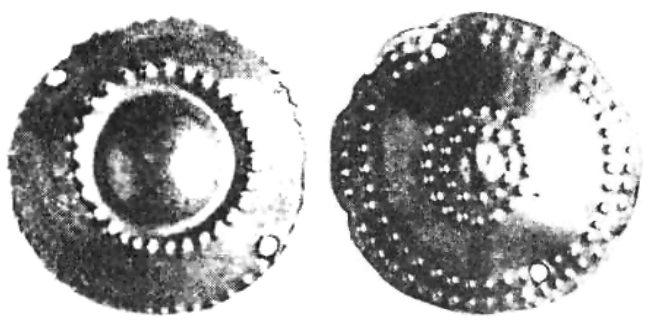

$\mathrm{D}=($ ?); $\mathrm{G}=0,96$ gr, 2,02 gr, 2,08 gr, 2,10 gr, 0,79 gr. Muzeul Național din Budapesta, Ungaria. 


\section{Tezaurul de la Ostrovu Mare}

Ostrovu Mare sat, comuna Gogoşu, județul Mehedinți

Perioada mijlocie a epocii bronzului.

În anul 1921 colecționarul bucureştean dr. George Severeanu a achiziționat - prin intermediul unui zaraf un important tezaur din epoca bronzului, adus de nişte țărani din satul Țigănaşi, din Oltenia. Tezaurul se compunea din 46 obiecte de podoabă din aur şi fusese descoperit întâmplător, în apropiere de Ostrovu Mare, de către un fierar din Craiova. $\mathrm{Nu}$ se ştie dacă piesele provin din morminte sau dintr-o aşezare, sau dacă ele formau un depozit. Sigur este că pe insula Ostrovu Mare au fost descoperite resturile unei aşezări şi morminte din epoca bronzului în care ceramica era ornamentată cu motive ce se regăsesc pe unele din podoabele acestui tezaur. Descoperirea de la Ostrovu Mare cuprinde: 33 discuri-falere, 10 inele de buclă, 3 brățări.

\section{Trei falere.}

Disc convex cu margine pliată vertical în jos şi 4 perforații marginale de prindere. Decor perlat; "umbo" circumscris de 3 cercuri concentrice înconjurate de 4 volute duble în $C$; pe contur bordură de linii oblice perlate. $\mathrm{O}$ piesă fragmentară.

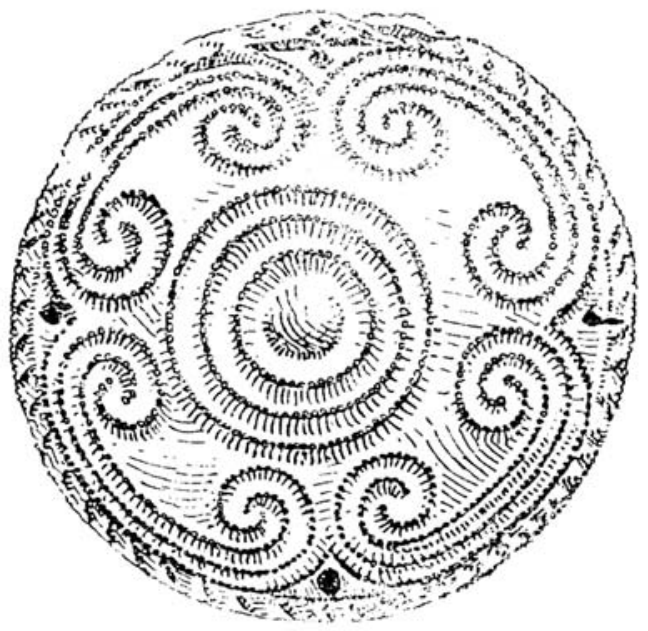

$\mathrm{D}=6,70 \mathrm{~cm}, 6,60 \mathrm{~cm}, 6,70 \mathrm{~cm} ; \mathrm{G}=9,53 \mathrm{gr}, 9,85 \mathrm{gr}$, 8,49 gr.

Muzeul Național de Istorie a României; inv. C 454-C 456.

\section{Două falere.}

Disc convex cu margine pliată vertical în jos şi două perforații marginale de prindere. Decor perlat; „umbo" circumscris de două cercuri concentrice înconjurate de 4 grupe de câte 3 linii paralele - cele marginale terminate la un capăt în volute; pe contur bordură din linii oblice perlate.

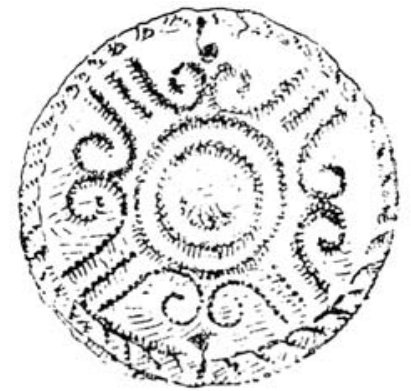

$\mathrm{D}=3,80 \mathrm{~cm} ; \mathrm{G}=3,40 \mathrm{gr}$ şi $2,86 \mathrm{gr}$.

Muzeul Național de Istorie a României; inv. C 457-C 458.

\section{Cinci falere.}

Disc convex cu margine pliată vertical în jos și două perforații marginale de prindere. Decor perlat; „umbo" circumscris de două cercuri concentrice înconjurate de undă etruscă din 5 volute în $S$; pe contur bordură din linii oblice.

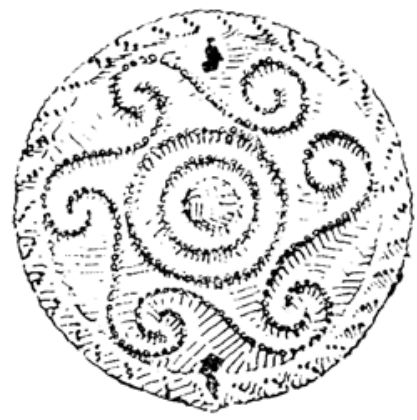

$\mathrm{D}=4,00 \mathrm{~cm} ; \mathrm{G}=2,66 \mathrm{gr}, 2,69 \mathrm{gr}, 3,00 \mathrm{gr}, 3,07 \mathrm{gr}$, 2,82 gr.

Muzeul Național de Istorie a României; inv. C 459, C 461-C462, C 467, C 471. 


\section{Cinci falere.}

Disc convex cu margine pliată vertical în jos şi două perforații de prindere marginale. Decor perlat; „umbo" circumscris de două cercuri concentrice înconjurate de undă etruscă din 6 volute în S; pe circumferință bordură din linii oblice.

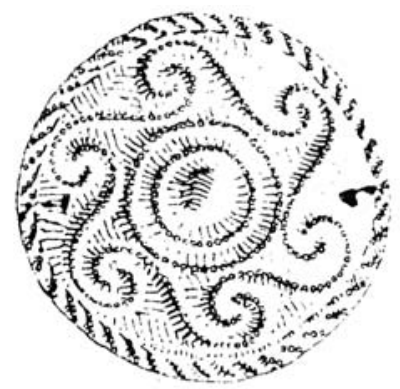

$\mathrm{D}=$ între $3,80 \mathrm{~cm}$ şi $3,90 \mathrm{~cm} ; \mathrm{G}=2,65 \mathrm{gr}, 3,05 \mathrm{gr}$, $2,60 \mathrm{gr}, 2,65 \mathrm{gr}, 3,07 \mathrm{gr}$.

Muzeul Național de Istorie a României; inv. C 460, C 464-C466, C 469.

\section{Trei falere.}

Disc convex cu margine pliată vertical în jos şi două perforații marginale de prindere. Decor perlat; „umbo" circumscris de două cercuri concentrice înconjurate de undă etruscă din 7 volute în S; pe contur bordură din linii oblice.

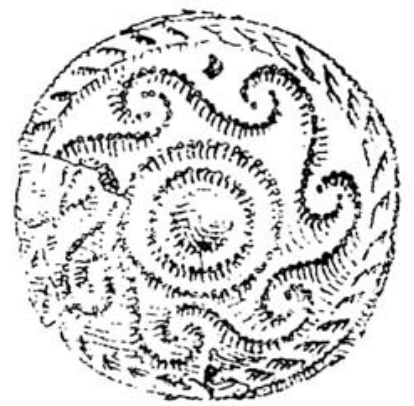

$\mathrm{D}=4,00 \mathrm{~cm}, 3,90 \mathrm{~cm}, 4,00 \mathrm{~cm} ; \mathrm{G}=3,12 \mathrm{gr}, 2,65$ gr, 3,02 gr.

Muzeul Național de Istorie a României; inv. C 463, C468, C470.

\section{Cincisprezece falere.}

Disc convex cu margine pliată vertical în jos şi două perforații de prindere marginale. Decor perlat; „umbo" circumscris de două cercuri concentrice, înconjurate de 4 volute duble în $\mathrm{C}$; pe circumferință bordură din 3 cercuri concentrice - cele exterioare reliefate.

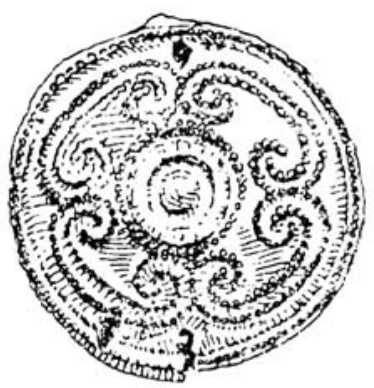

$D=$ între $3,40 \mathrm{~cm}$ şi $3,80 \mathrm{~cm} ; \mathrm{G}=$ între $2,15 \mathrm{gr}$ şi 2,44 gr.

Muzeul Național de Istorie a României; inv. C 472-C 486.

\section{Tezaurul de la Grăniceri}

Grăniceri sat, comună, județul Arad; n. v. Otlaca.

Perioada târzie a epocii bronzului.

Descoperire întâmplătoare, anterioară anului 1909.

\section{Faleră.}

Disc bombat, cu mic „umbo" circumscris de două cercuri concentrice perlate; decor în relief ciocănit cu motive spiralice - volute duble în $C$, perechi de volute - dispuse în 4 sectoare delimitate de benzi axiale; cerc perlat pe contur.

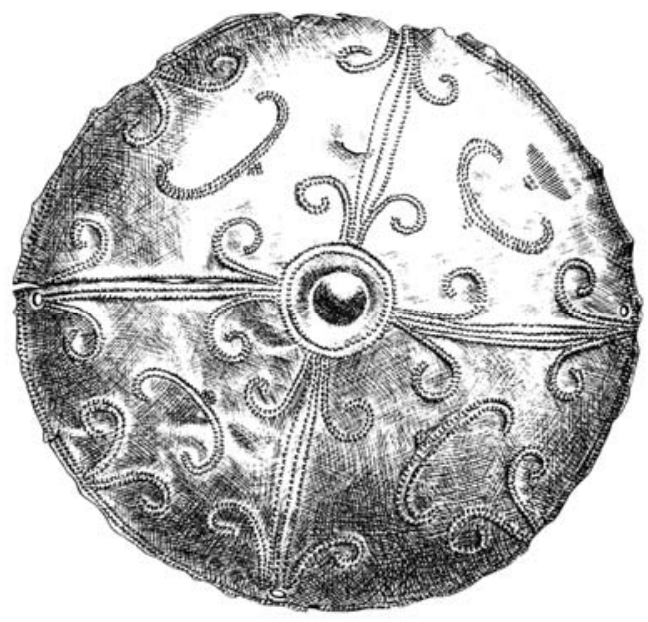

$\mathrm{D}=13,6 \mathrm{~cm} ; \mathrm{G}=79,6$ gr.

Muzeul Național din Budapesta, Ungaria.

\section{Faleră.}


Disc bombat, cu mic „umbo" circumscris de două cercuri concentrice perlate; decor în relief ciocănit cu motive spiralice - perechi de volute, pelta dispuse în raport cu două benzi axiale din linii punctate; marginal, într-unul din cele 4 sectoare, două păsări acvatice afrontate; cerc perlat pe contur.

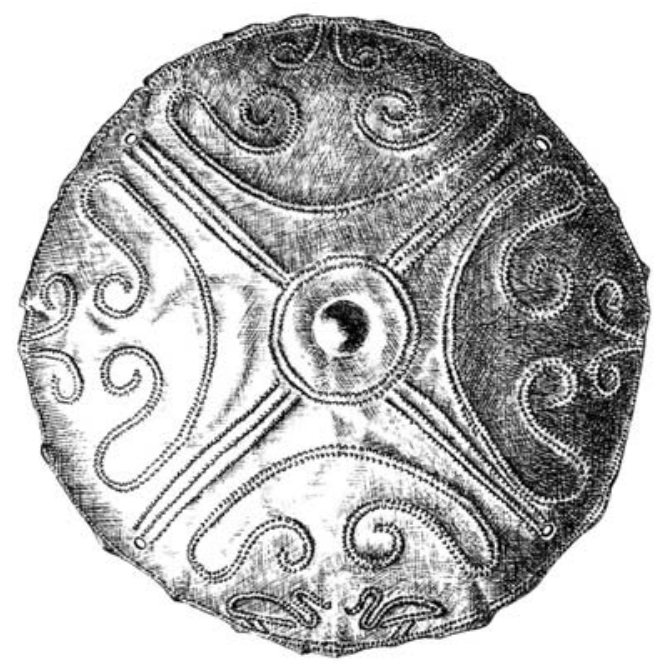

$\mathrm{D}=13-13,5 \mathrm{~cm} ; \mathrm{G}=82,31 \mathrm{gr}$.

Muzeul Naţional din Budapesta, Ungaria.

\section{Faleră.}

Disc bombat, cu mic „umbo" circumscris de două cercuri concentrice perlate; câmpul discoidal divizat în două registre prin câte două cercuri concentrice perlate - unul median, celălalt pe contur; în registrul central doi cai afrontați şi două siluete umane, schematizate; în registrul exterior cârcei în volută.

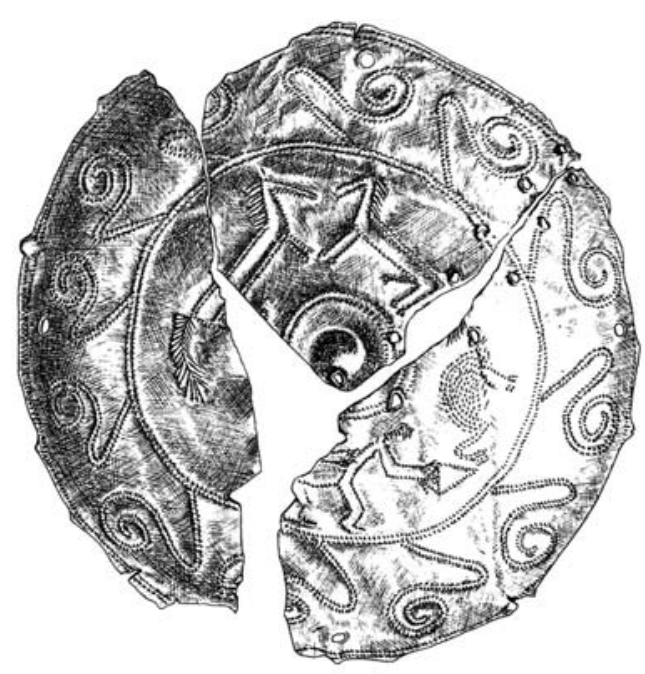

$\mathrm{D}=13,5 \mathrm{~cm} ; \mathrm{G}=85,55 \mathrm{gr}$.

Muzeul Naţional din Budapesta, Ungaria. 